\title{
Kebijakan Sektor Pertanian sebagai Awal Kebangkitan Ekonomi (Studi Kasus Taiwan Dalam Mengelola Komoditas Padi)
}

\author{
Deni Danial Kesa ${ }^{1 *} \&$ Cheng-Wen Lee ${ }^{2 *}$ \\ ${ }^{1}$ Banking and Finance Department, Vocational ProgramUniversity of Indonesia, \\ ${ }^{2}$ College of Business Chung Yuan Christian University Taiwan
}

\begin{abstract}
ABSTRAK. Potensi pertanian Indonesia besar, namun pada kenyataannya sampai saat ini sebagian besar dari petani kita masih banyak yang termasuk golongan miskin. Melihat kesuksesan Taiwan dalam mengembangkan inovasi dan memberdayakan sumber-sumber pertaniannya, banyak yang dapat dipelajari dalam sistem produksinya. Terutama dalam implementasi kebijakan yang diterapkan oleh Kementerian pertanian terhadap seluruh stakeholders di Taiwan. Untuk prospek masa depan Indonesia, sebagai langkah aplikatif dan prospek masa depan, yang harus diaplikasikan dalam sistem produksi beras di Indonesia diantaranya memaksimalkan produksi beras, setidaknya untuk swasembada karenaberas merupakan makanan pokok untuk Indonesia, dengan menambah perluasan lahan sawah di beberapa daerah yang potensial dan didukung oleh asas asas konservasi.

Pemerataan pembangunan sektor pertanian khususnya padi harus diimbangi dengan pengembangan teknologi terpadu yang konsisten. Kuantitas harus menjadi target jangka pendek,dengan diversifikasi lahan danpeningkatan kualitas produksi. Dibukanya akses akses perlindungan terhadap petani dalam aspek aspek manajemen, ketersediaan alat, dan subsidi yang berimbang sesuai dengan peraturan yang berlaku. Penerapan kebijakan sektor pertanian harus konsisten, dengan adanya UU yang berlaku dan rencana strategis pengembangan pertanian Indonesia bersinergi dengan semua pemangku kebijakan.
\end{abstract}

Kata Kunci : Kebijakan Sektor pertanian,rantai pasok beras, diversifikasi

ABSTRACT. Indonesian agricultural has big potential to developed, but in fact most of our farmers are still many who are categorized as poor. Looking at Taiwan's success in fostering innovation and empower agricultural resources, much can be learned in a production system. The policy implemented by the Ministry of agriculture and all stakeholders in Taiwan. For future prospects Indonesia, as applicable steps and future prospects, which should be applied in the rice production system in Indonesia such as maximizing the production of rice, with a maximum cost. Self-sufficiency for rice as staple food is main agenda for government , with expanding farmers rice fields in several potential areas and supported by the principle of conservation principles. Distribution of development agriculture particularly rice, should be offset consistent development of integrated technologies. Quantity must be short-term targets, with diversified land and production quality use unfettered access to farmers' access to protection in aspects of management, availability of equipment, and 
impartial subsidies in accordance with applicable regulations. Policy implementation should be consistent with the applicable law and Indonesian agricultural development strategic plan together with all stakeholders.

Keywords : Agricultural Sector Policy, the rice supply chain, diversification

\section{PENDAHULUAN}

\section{Latar Belakang}

Sektor pertanian mempunyai peranan strategis dalam struktur pembangunan perekonomian nasional sebuah negara. Sektor ini harus mendapatkan perhatian secara serius dari pemerintah dalam pembangunan ekonomi yang mapan. Mulai dari penyediaan lahan, teknologi, penanganan hama, menentukan pasar, proteksi, kredit hingga kebijakan lain. Perekonomian berbasis sektor agraris ataupun pertanian menjadi banyak pilihan motif kebangkitan ekonomi di dunia, bagaimana proses negara negara BRIC (Brazil, Rusia, India dan China) selain membuat banyak inovasi di bidang teknologi Industri, tapi juga menjadikan sektor pertanian penunjang roda pembangunan di sektor riil (buffer zone) dan memenuhi kebutuhan pangan nasionalnya.

Potensi pertanian Indonesia besar namun pada kenyataannya sampai saat ini sebagian besar dari petani kita masih banyak yang termasuk golongan miskin. Banyak hal yang harus kita lakukan dalam mengembangkan pertanian pada masa yang akan datang. Kesejahteraan petani dan keluarganya merupakan tujuan utama yang menjadi prioritas dalam melakukan program untuk kemajuan pertanian. Tentu hal itu tidak boleh hanya menguntungkan end user atau produsen saja, namun diarahkan untuk mencapai dasar yang kuat pada pembangunan nasional. Pembangunan adalah penciptaan sistem dan tata nilai yang lebih baik hingga terjadi keadilan dan tingkat kesejahteraan yang tinggi.

Pembangunan pertanian harus mengantisipasi tantangan demokratisasi dan globalisasi untuk dapat menciptakan sistem yang adil. Selain itu harus diarahkan untuk mewujudkan masyarakat yang sejahtera, khususnya petani melalui pembangunan sistem pertanian dan usaha pertanian yang kuat dan mapan, di mana sistem tersebut harus dapat berdaya saing, berkerakyatan, berkelanjutan dan desentralistik. Dengan alasan tersebut studi ini mencoba mengetengahkan gambaran perkembangan Taiwan mengenai kegiatan produksi bidang pertanian, terutama komoditas padi 
dikaitkan dengan dukungan kebijakan yang ada.

Taiwan terletak di daerah subtropis dengan banyak sinar matahari, memiliki gunung dan bukit-bukit terjal seluas dua pertiga wilayahnya, sehingga hanya sekitar 830,000 hektar lahan yang cocok untuk pertanian. Lahan pertanian ratarata seluas 1.1 hektar, sehingga sebagian besar sektor pertanian terdiri dari pertanian keluarga kecil. Namun Taiwan mengembangkan pertanian dengan memperkenalkan teknologi maju dan peralatan modern.

Produk pertanian Taiwan sangat beragam, output sangat tinggi. Sektor pertanian menjadi landasan yang kokoh bagi pertumbuhan ekonomi yang dinikmati Taiwan dalam beberapa dekade terakhir. Hasil pertanian tahunan di Taiwan adalah sekitar $\$ 11.8$ miliar, atau 1.5\% dari PDB. Tanaman ladang sebesar $43,36 \%$ dari angka ini, diikuti oleh perikanan sebesar $24,40 \%$, peternakan 32,11\%, dan kehutanan 0,13\%. Sekitar 540,000 orang bekerja di bidang pertanian, dan pendapatan tahunan rata-rata per rumah tangga pertanian adalah $\$ 28,000$.

Pertanian menyumbang $1.5 \%$ dari PDB Taiwan, tetapi pangsa ekonomi meningkat hingga $11 \%$ jika termasuk industri sekunder dan tersier yang berhubungan dengan pertanian seperti pengolahan makanan dan rekreasi.
Pertanian memainkan peranan penting dalam menyediakan makanan, mendukung pembangunan pedesaan, dan kontribusi terhadap pelestarian lingkungan. Apabila dibandingkan dengan negara negara lain di Asia, Taiwan relatif lebih menitik beratkan pada efisiensi pemanfaatan lahan secara modern, mengingat ketersedian lahan pertanian semakin terbatas, dikarenakan perubahan pola hidup dan gaya hidup masyarakat.

Lahan yang menjadi budidaya atau proyeksi lahan pertaniah padi baik sawah maupun ladang sekitar 813.000 Ha, dan jumlah yang maksimal untuk dipanen dan memenuhi kebutuhan domestik sejumlah 697.000 Ha. Dengan begitu komposisi antara lahan yang bisa dipanen dan lahan yang tersedia untuk padi rata rata $78,4 \%$ bisa dimanfaatkan secara efektif. Untuk memperkuat pemasaran beras dalam negeri, Departemen pertanian Taiwan membantu asosiasi petani lokal untuk membangun merek mereka sendiri dan mengadopsi strategi pemasaran lewat diversifikasi. Departemen pertanian Taiwan juga menjalankan program pendidikan memperkenalkan budaya sejarah dan tradisional padi dan beras sebagai turunannya kepada masyarakat dalam rangka untuk mempromosikan konsumsi lokal. Dengan terus-menerus mengamankan informasi mengenai produksi dan pemasaran beras, 
mempromosikan sistem evaluasi padi, memeriksa kualitas dan status higienis di pasar ritel, dengan mengamankan keamanan pangan dan perlindungan konsumen yang baik.

\section{Rumusan Masalah}

Berdasarkan latar belakang masalah tersebut maka studi ini akan terfokus pada beberapa analisis, sebagai berikut ; (1) Analisis berbagai kiat atau langkah kerja serta produksi pertanian khususnya padi di Taiwan, sehingga bisa menjadi faktor inisiasi kebangkitan ekonomi secara terintegrasi. (2) Rantai produksi komoditas padi di dalam negeri Taiwan sehingga dapat menjelaskan bagaimana Taiwan menerapkan teknologi dengan bantuan pemerintah dalam mengatasi serta melakukan inovasi.

\section{Tujuan Penelitian}

Tujuan dari kegiatan penelitian ini adalah : (1) Mengidentifikasi policy aplication atau pengaplikasian kebijakan pertanian padi, menganalisis pengaturan dan strategi secara holistik (best practice). (2) Merumuskan antisipasi dan prospek replikasi dan pengembangan kebijakan dan pengaturan kebijakan pertanian padi di Taiwan. (3) Manfaat teoritis dan aplikatif akan didapatkan dalam kajian ini oleh pihak-pihak yang berkepentingan. Aplikasi teoritis memberikan kesempatan dan keleluasaan bagi peneliti untuk menganalisis aplikasi kebijakan di Taiwan yang terjadi dalam kerangka perbandingan dan bisa memberikan masukan terhadap kebijakan di Indonesia.

\section{METODOLOGI PENELITIAN}

Kementerian pertanian Taiwan telah mengeksekusi berbagai langkah untuk mendukung pembangunan berkelanjutan dari industri beras, yang meliputi produksi direncanakan, pemuliaan varietas baru, memperbaiki teknik budidaya, menganjurkan penggunaan bahan kimia yang tepat untuk kontrol hama, membangun produksi beras khusus dengan pembagian zona pemasaran, mendorong pengendalian mutu sistem, dan mempromosikan certified agricultural standards/CAS (sistem sertifikasi pertanian termasuk padi).

Tujuannya adalah untuk membangun sistem manajemen dalam proses produksi, serta secara signifikan meningkatkan kualitas dan daya saing beras di pasar lokal maupun internasional.

Sehingga berdasarkan beberapa pemaparan tersebut, kajian ini akan mencoba menggambarkan kondisi perkembangan pertanian terkait komoditas padi sebagai berikut:

- Penerapan kebijakan pemerintah Taiwan terkait dengan pertanian padi 
dalam mendukungproses produksi beras

- Program pemerintah Taiwan dalam mendukung kebijakan produksi beras Jenis penelitian yang dilakukan adalah deskriptif, dengan menggambarkan kondisi yang mendukung terjadinya analisis produksi beras di Taiwan. Penelitian dilaksanakan dengan metode studi literatur dan survei. Studi literatur menggunakan berbagai data sekunder yang antara lain kebijakan di Taiwan, publikasi, serta hasil kajian sebelumnya.

Sedangkan survei dilakukan dengan metode wawancara FGD Focus Group groupdiscussion dalam skala kecil yang melibatkan berbagai narasumber. Diharapkan dengan gabungan antara data yang didapatkan dari data sekunder dan survey yang dilakukan bisa menjadi gabungan analisa yang komprehensif mengenai penerapan kebijakan pertanian padi yang menunjang produksi beras di Taiwan.

\section{ANALISIS DAN PEMBAHASAN}

\section{Analisa Langkah kerja Pemerintah}

Taiwan
Penerapan kebijakan Pemerintah Taiwan terkait dengan pertanian padi dalam mendukung proses produksi beras.Lokasi geografi Taiwan terletak antara 22-25"LU dan 120-122" BT serta berada di antara Jepang dan Filipina. Daerah ini termasuk daerah tropis Asia yang dihadapkan dengan tigabencana besar, yaitu cuaca dan angin dingin bersuhu rendah, hujan lebat serta angin ribut. Budidaya tanaman padi di daerah Taiwan dapat dibedakan menjadi dua musim, yaitu musim semi dan musim gugur. Pengolahan sawah dilakukan pada musim dingin dan gugur. Hampir 10 tahun terakhir struktur industri pertanian di Taiwan tidak mengalami perbedaan yang signifikan. lndustri pangan memiliki porsi sekitar $43 \%$ dari total keseluruhan nilai industri pertanian, dan nilai produksi beras mencapai sekitar $18 \%$ dari total nilai industri pangan.

Dari sekian banyak kebijakan yang ada dalam penanganan pertanian terutama padi dalam ranagka meningkatakan beras diantaranya sebagai berikut: 
Tabel 1.

Kebijakan dari tahun ke tahun Taiwan

\begin{tabular}{|c|c|}
\hline Tahun & Fokus Kebijakan \\
\hline 1949 & $\begin{array}{l}\text { Farmland Rent Reduction Implemented, tentang sewa tanah dan hak guna } \\
\text { tanah dan reformasi agraria di Taiwan }\end{array}$ \\
\hline 1950 & Rice-Fertilizer Barter Program' Implemented, program pupuk \\
\hline 1951 & $\begin{array}{l}\text { Sale of Public Lands' Implemented, bantuan lahan dengan menjual tanah } \\
\text { umum yang terbengkalai terkait dengan land reform }\end{array}$ \\
\hline 1953 & $\begin{array}{l}\text { First-Stage Land Reform: 'Land-to-the-Tiller Program' Implemented, } \\
\text { pelaksanaan reformasi lahan yang meluas untuk petani }\end{array}$ \\
\hline 1973 & $\begin{array}{l}\text { Rural Development Acceleration Program' Implemented, Pengembangan } \\
\text { Program Percepatan Pedesaan }\end{array}$ \\
\hline 1973 & $\begin{array}{l}\text { "Statue for Agriculture Development" Promulgated, penetapan model } \\
\text { pembangunan pertanian }\end{array}$ \\
\hline 1974 & $\begin{array}{l}\text { Guaranteed Rice Price Purchasing Program' Implemented, Jaminan program } \\
\text { pembelian beras oleh pemerintah }\end{array}$ \\
\hline 1979 & $\begin{array}{l}\text { Agricultural Mechanization Program' Implemented, kebijakan mekanisasi } \\
\text { pertanian }\end{array}$ \\
\hline 1982 & $\begin{array}{l}\text { Second-Stage Land Reform: Joint Cultivation, Contract Farming, and } \\
\text { Enlargement of Family Farm Size Implemented, tahap kedua reformasi lahan, } \\
\text { kerjasama budidaya, pertanian kontrak, dan perluasan jumlah lahan bagi } \\
\text { keluarga petani }\end{array}$ \\
\hline Tahun & Fokus Kebijakan \\
\hline 1984 & $\begin{array}{l}\text { 'First Six-Year Program to Convert Paddy Fields into Cultivation of Non-Rice } \\
\text { Crops(1984 1989)' Implemented, program enam tahun pertama konversi } \\
\text { lahan padi untuk non padi }\end{array}$ \\
\hline 1988 & $\begin{array}{l}\text { 'Rural Development Policy Guidelines' Implemented Pedoman Kebijakan } \\
\text { Pembangunan Pedesaan' Diimplementasikan }\end{array}$ \\
\hline 1989 & $\begin{array}{l}\text { "Statute of the Farmers' Health Insurance" Promulgated Statuta Asuransi } \\
\text { Kesehatan petani "' Diundangkan }\end{array}$ \\
\hline 1990 & $\begin{array}{l}\text { 'Second Six-Year Program to Convert Paddy Fields into Cultivation of Non-Rice } \\
\text { Crops (1990 1995)' Implemented. Tahap Kedua Enam-Tahun Program } \\
\text { Mengkonversi sawah padi ke Budidaya tanaman non beras Tanaman (1990 }\end{array}$ \\
\hline
\end{tabular}




\begin{tabular}{|c|c|}
\hline & atasikan \\
\hline 1990 & $\begin{array}{l}\text { Agricultural Automation Program' Implemented Program Otomatisasi } \\
\text { pertanian 'Diimplementasikan }\end{array}$ \\
\hline 1991 & $\begin{array}{l}\text { Integrated Agricultural Adjustment Program' Implemented } \\
\text { Penyesuaian Pertanian Terpadu 'Diimplementasikan }\end{array}$ \\
\hline 1994 & $\begin{array}{l}\text { Farmland-Irrigation Membership Fees Fully Subsidized by Government } \\
\text { Farmland - Biaya Keanggotaan Irigasi sepenuhnya disubsidi oleh } \\
\text { Pemerintah }\end{array}$ \\
\hline 1995 & $\begin{array}{l}\text { "Statute Regarding Old-Age Farmers' Welfare Allowance" Promulgated Statuta } \\
\text { Mengenai Tunjangan Kesejahteraan Hari Tua Petani "' Diundangkan }\end{array}$ \\
\hline 1995 & $\begin{array}{l}\text { Farm Land Release Program' Implemented Program Rilis Tanah pertanian } \\
\text { 'Diimplementasikan }\end{array}$ \\
\hline 1997 & $\begin{array}{l}\text { 'Cross-Century Agricultural Development Program' Implemented Program } \\
\text { Pembangunan Pertanian yang saling mensubsidi 'Diimplementasikan }\end{array}$ \\
\hline 1997 & $\begin{array}{l}\text { Paddy Field and Dryland Adjustment Program' Implemented } \\
\text { Penyesuaian lahan padi dan Ladang 'Diimplementasikan }\end{array}$ \\
\hline 2000 & $\begin{array}{l}\text { "Agricultural Development Act" Modified"Undang-undang Pembangunan } \\
\text { Pertanian" Diubah }\end{array}$ \\
\hline 2001 & $\begin{array}{l}\text { New Agenda for Agriculture in the } 21^{\text {st }} \text { Century' Implemented Agenda baru } \\
\text { Pertanian di Abad } 21 \text { 'Diimplementasikan }\end{array}$ \\
\hline 2003 & $\begin{array}{l}\text { Agricultural Finance Act" Promulgated , UU Keuangan Pertanian } \\
\text { "Diundangkan }\end{array}$ \\
\hline 2004 & $\begin{array}{l}\text { Statute for the Establishment and Management of Agricultural } \\
\text { Biotechnology Park" Promulgated Statuta untuk Pembentukan dan } \\
\text { Pengelolaan PertanianBioteknologi Park "Diundangkan }\end{array}$ \\
\hline 2004 & $\begin{array}{lcccccc}\text { Agricultural Financial Reform and Dual Financial } & \text { System Implemented } \\
\text { Pertanian Keuangan } & \text { dan Reformasi } & \text { Sistem } & \text { Keuangan Ganda } \\
\text { Diimplementasikan } & & & & & & \end{array}$ \\
\hline 2005 & The Agricultural Bank of Taiwan Set Up pendirian Bank Pertanian Taiwan \\
\hline 2006 & $\begin{array}{l}\text { New Agriculture Movement to Enhance Global Marketing and to Promote } \\
\text { Traceability' Implemented Gerakan Pertanian Baru untuk Meningkatkan } \\
\text { Pemasaran Global dan untuk Mempromosikan Lacak 'Diimplementasikan }\end{array}$ \\
\hline 2007 & Agricultural Production and Certification Management Act promulgated Produksi \\
\hline
\end{tabular}




\begin{tabular}{|c|c|}
\hline & ertanian dan Sertifikasi Manajemen Act "Diundangkan \\
\hline & $\begin{array}{l}\text { Agenda for Rural Reconstruction' Implemented Agenda rekonstruksi Pedesaan } \\
\text { 'Diimplementasikan, Agricultural Production and Certification Act Undang- } \\
\text { Undang Sertifikasi Produksi Pertanian }\end{array}$ \\
\hline Tahun & kan \\
\hline 2008 & $\begin{array}{l}\text { Implementing bylaw of Agricultural Products Market Transaction Act The } \\
\text { Agricultural Product Inspection, Sampling, and Testing Regulations Regulations of } \\
\text { COA's Bestowment of Agricultural Professional Accolade Perda Pelaksanaan } \\
\text { Transaksi Pasar Produk Pertanian, ,Inspeksi Produk Pertanian, Sampling, } \\
\text { dan Peraturan Pengujian, Peraturan penghargaan dari COA dibidang } \\
\text { keprofesian petani }\end{array}$ \\
\hline 2009 & $\begin{array}{l}\text { Regulations for Management of Agricultural Product Wholesales Market } \\
\text { Peraturan Pengelolaan Pasar Produk Pertanian Grosir }\end{array}$ \\
\hline 2010 & $\begin{array}{l}\text { The Plant Variety and Plant Seed Act, UU Varietas Tanaman dan Benih } \\
\text { Tanaman }\end{array}$ \\
\hline 2011 & $\begin{array}{l}\text { Enforcement Rules of Food Administration Act,Undang-Undang Penegakan } \\
\text { kebijakan pangan }\end{array}$ \\
\hline 2012 & $\begin{array}{l}\text { The Quality Agriculture Development Program and Diversification of Value in } \\
\text { Agriculture, Healthful agriculture, Excellence in agriculture, } \\
\text { LOHAS Agriculture, Program Pengembangan Kualitas Pertanian dan } \\
\text { Diversifikasi Nilai Pertanian, pertanian sehat, Keunggulan di bidang } \\
\text { pertanian, Pertanian LOHAS. }\end{array}$ \\
\hline
\end{tabular}

COA, Executive yuan, Taiwan. 2013. Diolah.

Dalam perkembangannya fokus pemerintah Taiwan hampir sama dengan yang dijalankan oleh Indonesia, dengan kebijakan yang dilakukan lewat rencana strategis pertanian dan tujuh gerakan masyarakat yang terdiri dari: (1) Lahan, (2)
Perbenihan dan perbibitan,

Infrastruktur dan sarana, (4) Sumber daya manusia, (5) Pembiayaan petani, (6) Kelembagaan petani, dan (7) Teknologi dan industri hilir. 
Tabel 2.

Program Pemerintah Indonesia dari tahun ke Tahun

\begin{tabular}{|c|c|}
\hline Tahun & Program \\
\hline 1959 & $\begin{array}{l}\text { Padi Sentra Varietas Si Gadis,Jelita, Dara dan Bengawan dengan label } \\
\text { Komando Operasi Gerakan Makmur }\end{array}$ \\
\hline 1965 & Sama dengan Padi Sentra Perbaikan kelembagaan dankredit \\
\hline 1968 & Intensifikasi Masal Pengenalan varietas PB5 dan PB8 (IRRI) \\
\hline 1969 & Bimas Gotong Royong, Penggunaan varietas PB5 dan PB8 ada KUD \\
\hline 1979 & Intensifikasi Khusus, Panca usaha tani, kelompok tani \\
\hline 1984 & Swasembada beras \\
\hline 1987 & Supra Intensifikasi Khusus Sapta Usahatani Penguatan \\
\hline 1995 & $\begin{array}{l}\text { Sistem Usahatani Berbasis Padi dengan Orientasi Agribisnis Varietas Cibodas } \\
\text { dan Membramo, Diversifikasi pertanian }\end{array}$ \\
\hline 1997 & Intensifikasi Berwawasan Agribisnis, Pendampingan petani \\
\hline 1998 & Gema Palagung, Sapta Usahatani Kredit Usaha Tani (KUT) \\
\hline 2000 & Corporate Farming, Konsolidasi petani sehamparan \\
\hline 2000 & Proyek Ketahanan Pangan \\
\hline 2001 & Pengelolaan Tanaman \& Sumberdaya Terpadu \\
\hline 2007 & $\begin{array}{l}\text { Program Peningkatan Beras Nasional, Bantuan benih, pupuk bersubsidi, pupuk } \\
\text { organik, perbaikan irigasi, Pengendalian operasi pasar terpadu,manajemen } \\
\text { pascapanen dankelembagaan }\end{array}$ \\
\hline 2010 & Renstra kementerian pertanian, 2010-2014 \\
\hline
\end{tabular}

Sumber : Kementerian Pertanian RI, diolah 2013

Semua kebijakan di kedua negara berdasar pada tujuan yang sama yaitu selain mencukupi kebutuhan beras dalam negeri, juga memberikan nilai lebih terhadap sektor pertanian padi yang mendorong komoditas beras. Banyak strategi maupun penanganan yang dilakukan kegua negara, Taiwan menerapka berbagai kebijakan yang cukup progresif diantaranya :Kebijakan mengenai lahan.Kalau kita bandingkan dengan luas daratan Indonesia, negara kita mempunyai lahan seluas sebesar 192 juta ha, terbagi atas 123 juta ha $(64,6$ persen) merupakan kawasan budidaya dan 67 juta ha sisanya $(35,4$ persen) merupakan kawasan lindung. Dari total luas kawasan budidaya, yang berpotensi untuk areal pertanian seluas 101 juta ha, meliputi lahan basah seluas 25,6 juta ha, lahan 
kering tanaman semusim 25,3 juta ha dan lahan kering tanaman tahunan 50,9 juta ha. Sampai saat ini, dari areal yang berpotensi untuk pertanian tersebut, yang sudah dibudidayakan menjadi areal pertanian sebesar 47 juta ha, sehingga masih tersisa 54 juta ha yang berpotensi untuk perluasan areal pertanian.Tercatat sebanyak 3.618.860 Ha lahan pertanian potensial. Dengan komposisi sebanyak $981.156 \mathrm{Ha}$ lahan datar , 981.277 $\mathrm{Ha}$ Lahan berbukit, serta 1.606.427 Ha yang bertipikal pegunungan pada tahun 2010 . Dengan demikian luas areal persawahan dan jumlah produksi lebih mudah ditingkatkan.

\section{Perkembangan pertanian di} Taiwan memiliki pola yang unik. Pada awal-awal tahun, pemerintah melakukan reformasi agraria untuk memberikan "tanah untuk penggarap", kemudian membuat penyesuaian kebijakan pertanian pada awalnya untuk memacu produktivitas yang lebih besar, dan kemudian untuk mengembangkan ekspor barang-barang pertanian mentah maupun hasil proses. Perkembangan ini pada gilirannya mengantarkan pada era pertumbuhan ekonomi yang pesat. Keberhasilan Taiwan dalam pengembangan pertanian skala kecil telah menjadi model untuk mengembangkan ekonomi di seluruh dunia. Prinsip-prinsip utama dari "penyehatan, efisiensi, dan kesinambungan" membentuk tulang punggung dari kebijakan pertanian yang dimotori oleh Kementerian pertanian atau COA (Council of Agriculture).

Meskipun

Taiwan mengklasifikasikan lahannya menjadi tiga klasifikasi, akan tetapi International Rice Research Institute (IRRI) mengelompokkan pertanian padi di Taiwan menjadi ernpat kelornpok, yaitu :

- Padi irigasi, yang berada di dataran dengan sistem pengairan terpadu, yang mendominasi kebanyakan sawah di Taiwan

- Padi tadah hujan, yang berada di daerah bukit yang hanya mengandalkan air hujan sebagai sumber pengairan.

- Padi dataran tinggi, yang di dominasi jenis gogo, yang tidak memerlukan banyak air sebagai sumber pengairan.

- Padi lahan pasang surut, yang berada di daerah pinggiran sungai di daerah delta , maupun hilir pantai atau sungai.

Pemerintah Taiwan mensubsidi tanaman lain melalui program pengalihan sawah dan lahan penduduk menggarap dengan system small land lord and big tenant atau meskipun tanah sedikit tapi bisa menyewa tanah yang lebih luas, hal ini dipandang efektif selain membuka lahan 
untuk padi juga menyerap tenaga kerja secara baik.

Kebijakan yang mencoba untuk memperluas lahan sebagai salah satu indicator peningkatan produksi beras menjadi perhatian yang cukup serius dari pemerintah Taiwan, mengingat banyaknya lahan yang terkonversi kedalam fungsi lahan lainnya.Lahan yang menjadi budidaya atau proyeksi lahan pertaniah padi baik sawah maupun ladang sekitar 813.000 Ha, dan jumlah yang maksimal untuk dipanen dan memenuhi kebutuhan domestik sejumlah 697.000 Ha. Dan sawah hanya berkisar dibawah diangka 411.000 Ha. Dengan begitu komposisi antara lahan yang bisa dipanen dan lahan yang tersedia untuk padi rata rata $78,4 \%$ bisa dimanfaatkan secara efektif.

Dalam mengidentifikasi jumlah lahan yang ada maka pemerintah taiwan melakukan pembenahan lewat pemanfaatan lahan dataran, bukit dan pegunungan yang diklasifikasikan berdasarkan fungsinya, sehingga membawa perubahan komposisi produksi hasil pertanian dalam kurun waktu sebelas tahun terakhir.

Gambar 1.

Luas lahan pertanian padi Taiwan

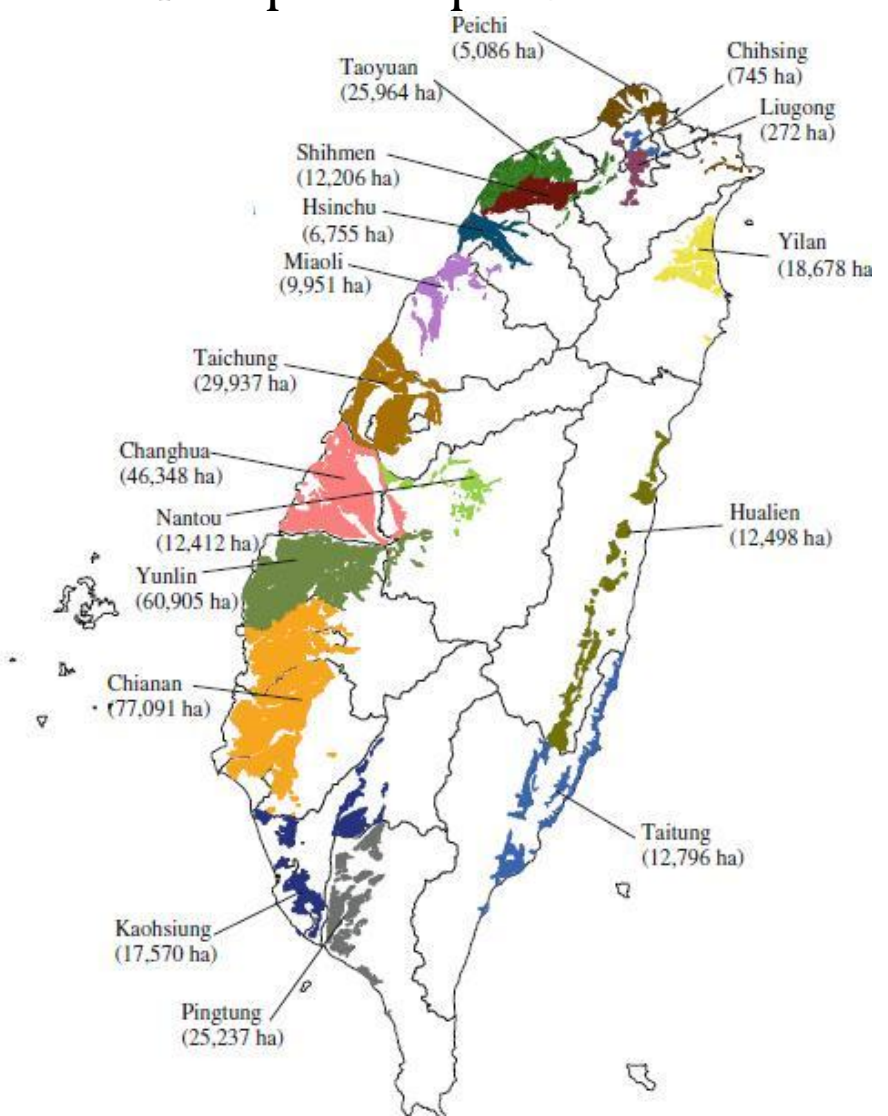

Sumber : Soil and Water Conservation Bureau., 2013.Diolah 
Kebijakan mengenai larangan konversi lahan sudah dijelaskan dalam UU pembangunan pertanian Taiwan :

\section{Article 9}

In maintaining the needs of agricultural development, the central competent authority shall coordinate overall development principles of territory plan, regulate the total amount of agricultural lands in demand and the quantity of agricultural lands of change, and comment and criticize such practices regularly.

Dan

\section{Article 10}

The delimitation or change of agricultural lands to nonagricultural purposes shall not affect the integrity of production environments and shall be subject to the prior approval of the competent authorities

Dalam menjaga kebutuhan pembangunan pertanian, pihak pemerintah Taiwan harus berkoordinasi prinsip-prinsip pengembangan keseluruhan rencana wilayah, mengatur jumlah total lahan pertanian dalam perubahan permintaan dan jumlah lahan pertanian, serta memberikan masukan terhadap termutakhir secara regular

Meski demikian tantangan perubahan fungsi lahan juga menimpa Taiwan, dengan banyaknya sentra produksi padi beralih ke komoditas lain misal buah pinang. Permintaan yang terus meningkat pada tahun 1990-an mengakibatkan perluasan kawasan budidaya untuk buah pinang. Petani sangat antusias untuk menanam tanaman buah pinang karena dalam tahun yang baik, pendapatan bisa 10 kali lebih tinggi daripada menanam padi.

Menanggapi Delimitasi atau perubahan lahan pertanian ke nonpertanian, maka diterapkan standar tinggi untuk tidak merubahnya termasuk tujuan yang tidak akan mempengaruhi integritas lingkungan produksi padi dan harus tunduk pada persetujuan dari pihak yang berwenang mengenai syarat syarat perubahannya.

\section{Otoritas Pertanian di Taiwan.}

Kementerian pertanian adalah pihak yang berwenang pada pertanian, kehutanan, perikanan, peternakan dan urusan makanan di Taiwan. Lingkup tanggung jawabnya termasuk membimbing dan mengawasi kantor provinsi dan kota di wilayah ini. COA (Council of Agriculture) berada di bawah Executive of Tuan (lembaga eksekutif pemerintah Taiwan). 
Inovasilah yang mendorong kemajuan pertanian di Taiwan, dan menjadikan Taiwan rumah bagi banyak teknologi yang paling canggih di dunia pertanian, dengan memimpin keunggulan kompetitif negeri ini di berbagai bidang seperti peternakan, bibit produksi, reduksi efek rumah kaca, kontrol lingkungan, dan transportasi maritim komoditas jarak jauh.

Kementerian pertanian atau COA terdiri dari bagian perencanaan, peternakan, penyuluhan pelayanan petani, kerjasama internasional, Ilmu dan Teknologi, bagian irigasi dan teknik, serta beberapa kantor administrasi lainnya.Ada beberapa badan yang cukup signifikan dalam mengawal kemajuan pertanian di Taiwan diantaranya AFA (Agriculture and Food Agency) serta DARES (District Agricultural Research and Extension Station), TPDF ( Taiwan Provincial Department of Food), Taiwan Agricultural Research Institute (TARI), Council of Agriculture, Executive Yuan, China Grain Products Research \& Development Institute. Semualembaga tersebut membantu kementerian pertanian dalam mengelola berbagai kebutuhan serta pengembangan pertanian baik terkait dengan pengaturan regulasi demi tercapainya tujuan kesehatan, efisiensi dan keberlanjutan bagi pembangunan pertanian termasuk beras di Taiwan.
Departemen pertanian Taiwan juga menjalankan program pendidikan memperkenalkan budaya sejarah dan tradisional padi dan beras sebagai turunannya kepada masyarakat dalam rangka untuk mempromosikan konsumsi lokal.Agrobisnis didorong oleh COA (Council of Agriculture) untuk membangun ilmu pertanian dan teknologi perkebunan serta peternakan, sebagai contoh mereka dapat membangun Taiwan sebagai pusat produksi bunga global juga untuk buahbuahan tropis, dan pemasok bibit ternak dan tanaman ke seluruh wilayah Asia Timur. Memiliki teknologi terdepan adalah kekuatan yang akan membawa Taiwan untuk mengadopsi penerapan tentang penerapan model bisnis baru dan lebih canggih untuk sektor pertanian. Lembaga riset pertanian bertugas memberikan terobosan serta inovasi yang memperkuat pengolahan lahan, pemasaran, dan penerapan teknologi tinggi dalam proses produksinya.

Pada 1950 atau masa awal program pemerintah di bidang pertanian, 90\% warga petani Taiwan mayoritas menanam padi, tebu untuk gula, teh, dan tanaman lainnya. Dua dekade kemudian, pemerintah secara agresif mengejar industrialisasi berskala tinggi dibidang informasi dan teknologi yang menyebabkan ekspor pertanian tertinggal dari impor pertanian. Pada 1999, 
pertanian hanya 3 persen dari PDB (pendapatan domestik bruto) Taiwan dibandingkan dengan 32,2 persen pada 1952. Pada tahun 2010 padi menempati persentase hanya di kisaran 18,2 persen masih kalah dengan sayur dan buah buahan, nilai output pertanian terhadap perekonomian nasional meningkat setengah kali lipat karena perbaikan produktifitas secara keseluruhan

\section{Peranan lembaga penelitian.}

Teknologi yang inovatif adalah kekuatan dan sumber yang akan menjadikan kemajuan pertanian Taiwan mempunyai daya saing dan berkembang secara berkelanjutan. Berdasarkan pada kebutuhan untuk pengembangan industri, Kementerian pertanian Taiwan selain lembaga lembaga yang sudah terbentuk dan dibawah kordinasi pemerintah , mereka juga mempercayakan universitas dan lembaga penelitian swasta untuk melakukan proyek penelitian dari berbagai disiplin ilmu.

Bidang utama penelitian meliputi perbaikan varietas tanaman dan praktikpraktik budidaya, pengolahan pasca panen, pengembangan tanaman transgenik, kultur jaringan tanaman, pemupukan yang efektif, pengelolaan tanah, budidaya organik, teknik pertanian yang aman,mekanisasi pertanian dan otomatisasi, pupuk hayati, pengontrolan polusi, daur ulang limbah, sistem pemasaran elektronik, makanan sehat, pengolahan makanan dan lain lain. Hasil dari proyek penelitian penting dalam mempromosikan modernisasi dan peningkatan kualitas industri pertanian dalam berbagai aspek

Dibawah COA ada beberapa lembaga penelitian yang membantu pertanian termasuk pertanian padi diantaranya :

- Agriculture and Food Agency termasuk cabang daerah utara, tengah, selatan, dan barat), riset umum terkait dengan keadaan beras yang secara umum

- Agricultural Chemicals and Toxic Substances Research Institute, penelitian tentang kondisi tanah/lahan pertanian termasuk sawah dan jenis pupuk yang baik

- Taoyuan District Agricultural Research and Extension Station, balai pendampingan petani termasuk petani padi.

- Miaoli District Agricultural Research and Extension Station

- Taichung District Agricultural Research and Extension Station

- Tainan District Agricultural Research and Extension Station

- Kaohsiung District Agricultural Research and Extension Station

- Hualien District Agricultural Research and Extension Station 
- Taitung District Agricultural Research and Extension Station

- Taiwan Seed Improvement and Propagation Station, balai penelitian dan rekayasa benih

- Taiwan Agricultural Research Institute (termasuk Chiayi Agricultural Experiment dan Fengshan Tropical Horticultural Experiment)

Gambar 2 .

Alur dan fungsi salah satu lembaga penelitian pertanian di Taiwan

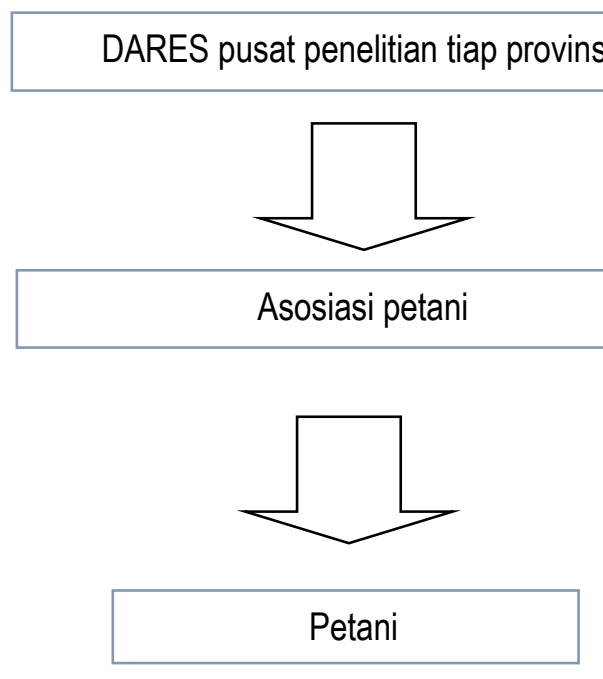

Sumber: Dares Kaohsiung, 2012
Dukungan Teknis dari DARES :

1. Pembibitan

2. Perbaikan panen

3. Perbaikan kualitas lahan, pemupukan

4. Mengontrol hama dan penyakit tanaman

5. Peningkatan kualitas manajemen pertanian

6. Peningkatan serta perancangan mesin dan peralatan yang mendukung pertanian
Menurut UU Pembangunan pertanian lembaga penelitian memegang peranan yang cukup penting, dan pemerintah Taiwan mengakomodirnya dengan pengalokasian lembaga serta pembiayaan penelitian.

Article 64

$$
\text { In order to upgrade }
$$
agricultural science and technology level and promote the transformation of agricultural industries, the competent authorities shall supervise and request their respective affiliated agricultural research and experiment institutes to strengthen the cooperation between research and experiment sectors and agricultural industry sectors and to promote the 
technology development in agricultural industries

Lembaga penelitian yang bertugas dengan pengembangan teknologi inovatif telah membuat kontribusi yang cukup besar bagi keberhasilan pertanian padi Taiwan selama bertahun-tahun melalui transfer teknologi. Pada tahun 2011, ada 126 transfer teknologi pertanian, dengan pembayaran royalti sekitar NT \$ 69 juta (US \$ 2,34 juta).

Menyadari peran penting penelitian ,sektor swasta juga dilibatkan dalam pengembangan dan komersialisasi produk pertanian, COA menerapkan program lima tahun pada tahun 2009 yang bertujuan mempromosikan kerjasama akademisiindustri dalam penelitian bioteknologi pertanian yang pada akhirnya akan meningkatkan nilai output sektor pertanian termasuk padi dengan 50 persen di tahun 2013. Pada Desember 2011, program ini telah mendanai 431 proyek yang menarik investasi total NT \$
312.000.000 (US \$ 10.590.000) dari 217 perusahaan.

Taiwan memainkan peran utama dalam pengembangan teknologi pertanian dan, melalui banyak transfer teknologi yang pertanian, hal tersebut memberikan kontribusi terhadap perbaikan kehidupan para petani padi, karena mereka akan diberikan pengetahuan terbaru dari hasil penelitian para ahli yang telah teruji.

Aplikasi teknologi. Keunggulan teknologi pertanian Taiwan termasuk perkembangan pertanian padi adalah sistem teknologi tepat guna, karena proses pertanian di dukung dengan mesin yang seluruh prosesnya tidak banyak menyerap tenaga manusia. Untuk meningkatkan teknologi produksi dan meningkatkan standar hidup di pedesaan, COA mengadakan kursus pelatihan profesional, menyediakan pekerjaan pertanian, mengadakan bahan pelajaran online, dan membentuk sebuah situs untuk menjamin akses kesempatan belajar yang lebih luas.

\section{Gambar 3}

Alur perkembangan pemikiran adaptasi teknologi pertanian di Taiwan 


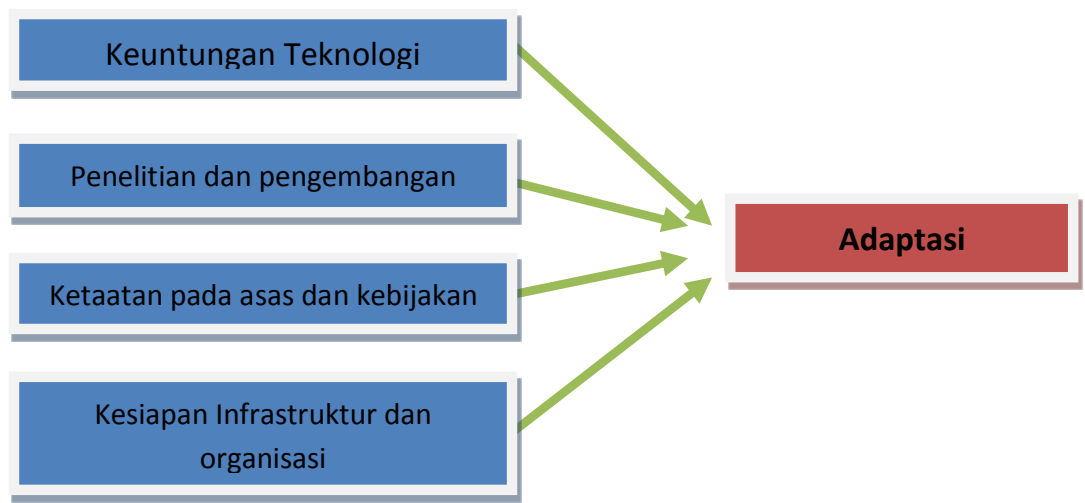

Selain itu, COA juga memanfaatkan sumber daya dari stasiun penelitian dan penyuluhan, asosiasi petani, sekolah pertanian, dan universitas-universitas untuk menyediakan pelajaran tambahan mengenai pertanian dan kerjasama penelitian. Sesuai dengan amanat UU pembangunan pertanian Taiwan :

Article 28

The central competent authority shall formulate plans for agricultural mechanization development, guide farmers or farmers' organizations in purchasing and utilizing the agricultural machinery and further assist in loan applications or subsidization for the aforementioned purposes.

Article 29

The price of electricity, gasoline and water for powering agricultural operation shall not be higher than that of those for general industrial purposes.
Electricity fee for powering agricultural operation are not calculated in terms of progressive increment, and during the suspension period of power use, basic electricity fee is to be exempted.

Dalam menerapkan pembangunan dan teknologi pertanian padi, pihak terkait yaitu COA harus memberikan bimbingan terkait dengan mekanisasi dan otomatisasi pertanian sebagai bagian dari adaptasi teknologi terhadap sektor pertanian, hal tersebut merupakan jalur langsung untuk meningkatkan efisiensi produksi dan kualitas produk, dan tuntutan tenaga kerja sementara meningkatkan kekuatan lingkungan kerja, meski biaya yang dikeluarkan juga tidak sedikit. Sejak tahun 1990, pemerintah memperkenalkan langkah-langkah strategis seperti penyiapan lahan, tanam, panen dan pengeringan padi dan tanaman lainnya, 
dengan hasil mencapai mekanisasi hingga $98 \%$.

Otomatisasi dibantu pengembangan secara teknis juga telah dikembangkan dan diterapkan pada produksi tanaman padi serta hortikultura dan khusus untuk meningkatkan lingkungan yang lebih baik dalam pengelolaan pertanian serta sistem produksi dan panen. Pemeriksaan produk dan penilaian juga dapat dilakukan dengan cara non-destruktif (mengurangi kerusakan) dan presisi tinggi. Teknologi yang berkembang kemudian diperluas ke petani, organisasi petani, dan produsen. Sistem pertanian terpadu dengan mekanisasi, otomatisasi dan informasi, serta dapat diterapkan secara efektif dan kompetitif dalam skala besar di masa depan.

Pada tahun fiskal 2011, para petani membeli 3.020 set mesin, dipilih dari 10 jenis mesin yang baru dikembangkan, dengan subsidi pemerintah $30-40 \%$ dari harga pembelian. Di antaranya adalah jenis mesin pemotong, mesin pengolah tanah, mesin penanam, dan mesin pengering. Pinjaman hingga NT \$ 679 juta dilaksanakan untuk membantu petani dalam pembelian mesin pertanian dan sistem otomatis. Langkah-langkah khusus seperti menerbitkan sertifikasi mesin pertanian, kupon bebas Pajak untuk bahan bakar pertanian dan lisensi kendaraan pertanian dilakukan untuk membantu petani mengurangi biaya bahan bakar motor pada proses produksi pertanian.

Irigasi. Selain teknologi, yang disediakan dengan penelitian yang terbaru, padi di Taiwan, didukung juga oleh sarana pengairan yang cukup kondusif.Irigasi adalah sumber kehidupan dari pertumbuhan padi. Pasal 10 mengenai tugas dari asosiasi irigasi dalam UU irigasi Taiwan menyatakan bahwa :

1.The initiation, improvement, maintenance, and management of farmland irrigation operations.

2.Precautionary and rescue measures in the event of disasters and threats on farmland irrigation association operations.

3.The raising of expenditure and institution of funds for farmland irrigation operations.

4.Research and development projects for the interests of farmland irrigation operations.

5.The collaboration with central government over land, agricultural, and industrial policies, and rural village development programs.

6.Affairs and projects consigned by supervising authorities

Asosiasi irigasi pada intinya melakukan perbaikan, dan tindakan manajemen terhadap system tata air 
pertanian. Penelitian, dan tata kelola lainnya, berkordinasi dengan pemerintah Taiwan mengenai masalah lahan, kebijakan industry dan program pembangunan pedesaan.

Di barat Taiwan, dari utara ke selatan, sumber daya air meliputi Sungai Danshui, Sungai Da-an, Sungai Houlong, Sungai Dajia, Sungai Wu, Sungai Zhuoshui, Sungai Zengwen, dan Sungai Gaoping. Di bagian timur Taiwan, sumber daya air untuk sawah termasuk Sungai Beinan, Sungai Xiuguluan, Sungai Hualien, dan sungai Lanyang. Sistem irigasi memberikan banyak sungai bersih, kaya nutrisi air. Selain itu, berkat pembangunan fasilitas irigasi, masingmasing daerah aliran sungai tersebut di atas memiliki sistem irigasi yang luas. Karena sumber air dan jenis tanah mereka yang bervariasi,maka peralatan mekanik modern yang digunakan oleh petani saat ini tidak sama, setiap wilayah Taiwan memproduksi beberapa jenis beras unggul khas lokal. Hal ini telah membuat Taiwan menjadi salah satu penghasil beras berkualitas.

Penyediaan pupuk. Situasi yang sama dengan pupuk, penyediaan pupuk lewat rekomendasi para peneliti menjadi salah satu indicator keberhasilan produksi beras Taiwan. Pupuk adalah bahan penting untuk potensi produksi lahan pertanian, yang digunakan untuk meningkatkan potensi produksi, mempertahankan hasil yang tinggi dan kualitas produk. Mereka akan menurunkan kesuburan tanah, apabila tidak diterapkan dengan benar atau kualitas pupuk yang kurang baik. Oleh karena itu sangat penting untuk meningkatkan manajemen pada kontrol kualitas pupuk komersial dan petani untuk menggunakan pupuk dengan pelatihan yang tepat. Sementara beberapa praktek yang tepat diperpanjang seperti penggunaan pupuk organik dan pupuk hayati, pupuk hijau selama musim antara sebelum masa tanam dengan mengurangi derajat keasaman, dan melestarikan kesuburan tanah.

Pada tahun 2011, selain untuk meningkatkan pemeriksaan aplikasi baru dari merek pupuk, kualitas dan survei pelabelan pupuk dilakukan untuk 776 kasus, yang merupakan sampel dari pasar dan pabrik pupuk, dan 140 kasus ditemukan memiliki beberapa kondisi tidak mengikuti aturan pupuk di Taiwan. Ada 488 kursus yang diselenggarakan pada teknis pemupukan yang tepat termasuk indoor training, lokakarya pelatihan, dan praktik lapangan. Dan pengecekan online di The Fertilizer Registration Management System (http://agrapp.coa.gov.tw/WFR/).

Dalam rangka untuk menempatkan sistem pemupukan yang tepat pada pola pertanian menurut sifat-sifat tanah, ada 
44.406 sampel didiagnosis setelah sampel dikumpulkan dari sifat tanah dan kandungan gizi tanaman daun serta dianalisis. Pemerintah Taiwan juga menggalakkan penggunaan pupuk alam , lahan pertanian didorong untuk menggunakan kompos berkualitas dengan menggantikan sebagian pupuk kimia yang digunakan secara bertahap, meskipun masih mensubsidi sebagian besar petani.

\section{Rantai produksi komoditas padi}

Rantai Pasok beras . Dalam proses setelah hasil panen dan tersebarnya beras, disediakan sebagai stok untuk public atau negara maka AFA menunjuk pihak pihak yang dipercaya dan ahli dalam bidang bidangnya sesuai ketentuan UU pangan , yang menyatakan bahwa :

Article 8

The competent authority may commission contracted public stock keeper to collect, store, mill and distribute public stock.

The conditions that the contracted public stock keeper and their warehouses must possess, the collection, storage, milling, distribution, and other administration items for public stock shall be promulgated by the competent authority.
Penyimpanan dan pengumpulan stock padi untuk kepentingan umum di lakukan oleh CPSK atau Contracted public stock keeper. Ketika sudah menjadi kontrak, maka CPSK bertugas untuk menjaga, mengumpulkan, menyimpan , memproses dan mendistribusikan beras dengan sepengetahuan pihak berwenang dalam hal ini AFA dibawah COA. Dengan syarat syarat yang ditetapkan missal:

- Terdaftar, berpengalaman dibidangnya, menjamin kapasitas penyimpanan,mempunyai pengawas kualitas yang disetujui oleh AFA, bisa mengimplementasikan Agri food network information system,mempunyai kapasitas pengering padi sampai dengan 50 ton.

- Memiliki masing masing tangki penyimpan untuk beras kasar dan beras putih masing masing 30 ton dan mempunyai kapasitas giling dan sortir per jam 3 ton sesuai Chinese national standard.

- Mampu menyimpan 2000 ton atau lebih. Namun, dengan izin tertulis dari AFA, AFA dapat meninjau kebutuhan kemampuan penyimpanan di wilayah di bawah kendali mereka, dan menyesuaikan kondisi kemampuan penyimpanan ketika jumlah rata-rata mengumpulkan 
beras dari empat panen terakhir apabila kurang dari 500 ton.

- Syarat syarat teknis lainnya

Secara sederhana rantai pasok yang terjadi di Taiwan dalam pemenuhan produksi beras adalah sebagai berikut:

- Proses pengiriman diawali dari pabrik atau tempat pengolahan padi menjadi beras.

- Penerapan biaya untuk ekspor seandainya padi tersebut akan diekspor

- Inspeksi, misal untuk kualitas,keamanan dan penanganan

- Memeriksa segel;

- Pengiriman dari tempat pengolahan ke grosir
- Penyimpanan, di grosir atau di distributor;

- Fumigasi, jika diperlukan;

- Pengemasan ulang apabila dijual dalam bentuk kemasan.

- Pasar bebas, penentuan harga ditentukan kualitas beras.

(Adaptasi dari Sumber: Londoño-Kent Kent dan (2003), yang diadaptasi di Ferrantino (2006).)

Sedangkan apabila proses rantai pasok yang berkaitan dengan ekspor dan impor maka ada bagan yang biasanya di kenal dalam proses penetrasi pasar dalam sebuah negara .

Gambar 4.

Alur Supply chain terkait proses penentuan harga

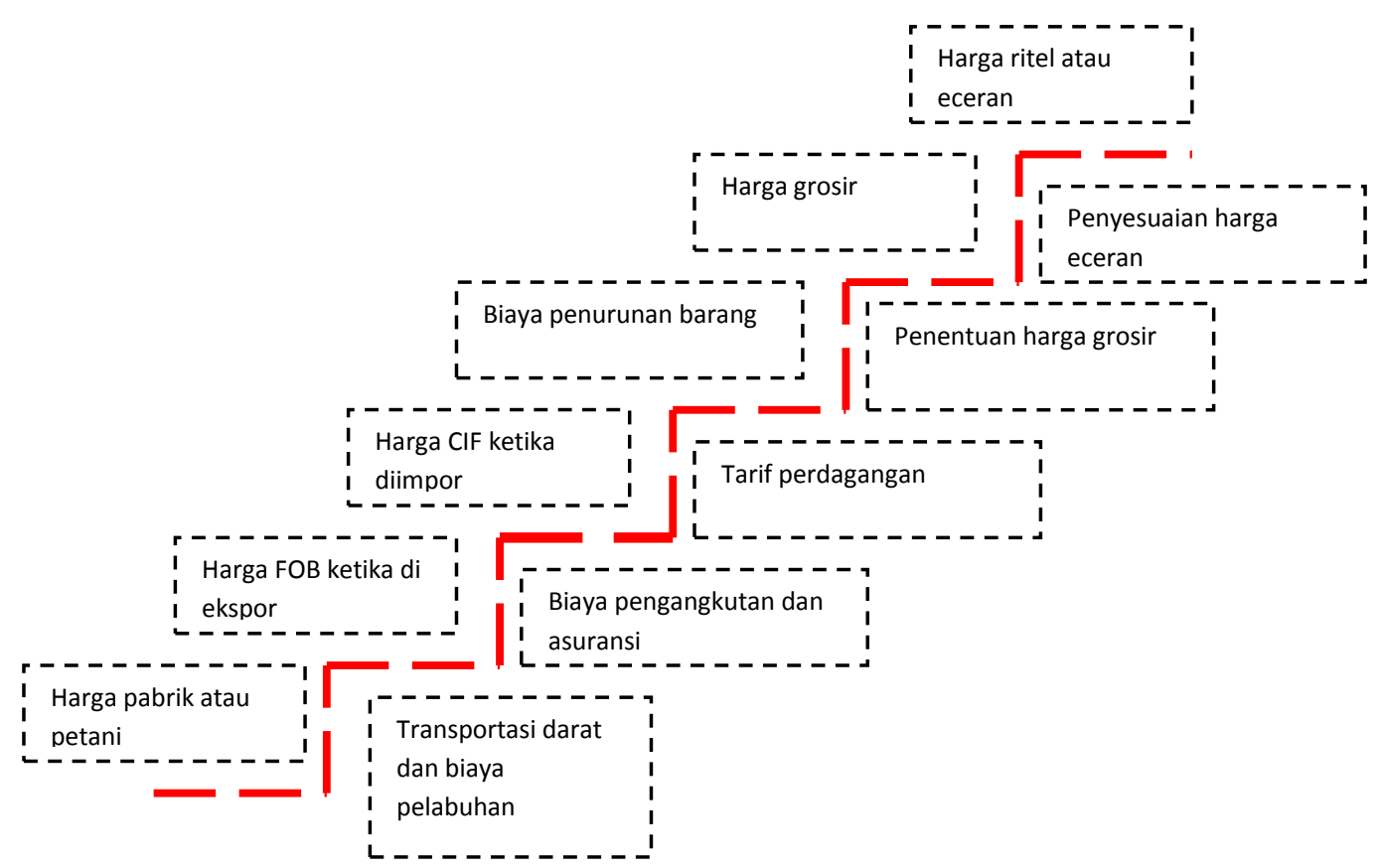


Free On Board (FOB) adalah bagian dari Incoterms. Penyerahan barang dengan Free On Board dilakukan di atas kapal yang akan melakukan pengangkutan barang. Selain itu yang memiliki kewajiban untuk mengurus formalitas ekspor adalah pihak penjual. Persyaratan dengan menggunakan FOB hanya dapat dilakukan untuk pengangkutan laut dan antar pulau semata.CIF Adalah singkatan dari Cost, Insurance and Freight artinya Harga penawaran anda selain mencakup harga barang, biaya kapal, juga termasuk asuransi.dengan kata lain harga barang disatukan dengan ongkos kirim dan biaya asuransi barang, selain FOB, dasar ini menjadi perhitungan bea-bea suatu barang.

Istilah dalam system perdagangan atau pengecer padi sepertti tercantum dalam UU pangan dianggap sebagai salah satu unsur perdagangan pangan :

\section{Article 3}

\section{Business of a food dealership} shall include the following:

1. Sales: Retail and wholesale.

2. Brokerage.

3. Warehousing.

4. Milling: dehulling, rice milling, rice flour grinding, flour grinding.
Bahwa bisnis pangan diantaranya menjual baik grosir maupun eceran, menjadi perantara penjualan, penyimpanan padi di gudang, pengolahan padi termasuk huller, milling, pembuatan tepung beras dan lain lain.Untuk proses produksi didalam negeri ada beberapa proses yang sempat teridentifikasi di salah satu produsen beras di Houbi town, Tainan county proses produksi beras melalui rangkaian proses sebagai berikut :

Dengan variasi harga yang ditentukan pasar dan biaya produksi serta kualitas produk yang dihasilkan, konsumen bisa memilih kualitas dan harga beras sesuai dengan kemampuan dan hukum pasar.Salah satu cara melihat para pelaku pasar dengan melihat demand pasar, berikut ini adalah para pelaku pasar padi atau beras yanga da di Taiwan berdasar UU mengalir berlaku untuk izin demander melalui pasar produk pertanian grosir dan disetujui oleh otoritas yang berwenang setempat akan ada demander di pasar grosir. Yaitu :

\section{Wholesale market demander.}
1. The retailer.
2. The reseller.
3. The shipper.
4. The exporter.
5. The processer.
6. The great quantity consumer. 
Retailer dilevel eceran, reseller dengan jumlah yang lebih besar, shipper pembeli antar pulau, exporter menjual ke luar Negara, The processer pembeli yang akan mengolah ke bentuk lain missal tepung, mie dll. Sedangkan yang lain adalah pembeli perseorangan yang membeli dalam jumlah besar missal karena kebutuhan di waktu waktu tertentu.

Kebijakan Harga. Pengenalan beras impor telah menyebabkan diversifikasi pasar beras Taiwan menjadi beraneka ragam berdasarkan jenis dan varietas padinya. Kesegaran padi, varietas, dan asal-usul serta standard industri akan mempengaruhi harga. Antara beras putih curah yang berkisar sekitar 34.23 NT $\$$ akan sangat berbeda dengan beras yang dikemas dengan baik lewat vacuum package, standar GAP,CAS dan TAP yang berkisar sekitar 100 sd 120 NT\$.Hal tersebut sudah sejalan dengan pelaksanaan UU yang mndasarkan pada wewenang pemerintah dalam menstabilkan harga :

Article 44

In maintaining the balance between agricultural production and distribution as well as reasonable prices of agricultural products, the competent authorities may organize domestic and international promotion activities or designate agricultural products to be produced and purchased with guaranteed prices by contract as concluded between parties of supply and demand.

Article 45

In response to prices fluctuations of domestic and international agricultural products and in order to stabilize the production and distribution of agricultural products, the government shall designate important agricultural products for the establishment of a stabilization fund either by the government or private sectors. The rules and regulations for the establishment, custody and utilization of the said fund shall be formulated by the central competent authority in concert with other authorities concerned.

Promosi beras Taiwan dilakukan disela sela masa produksi dua kali dalam satu tahun dengan masa selingan sebanyak satu kali, yaitu panen pertama, panen kedua, dan tanaman antara. Beras mencoba dipromosikan menjadi bahan baku pembuatan makanan yang berbahan dasar terigu, gandum dan sejenisnya yang didatangkan secara impor. Pembuatan kue bulan, roti beras, kue beras nanas, krim pembersih muka kini bisa dibuat dengan 
bahan dasar yang terbuat dari beras . Beras telah berubah menjadi alat substitusi bagi kampanye pemenuhan pangan Taiwan. Pemanfaatan beras sekarang tidak hanya sekedar untuk makan sehari hari saja akan tetapi juga sudah merambah industri, dengan cakupan fungsi yang semakin luas.

Orang-orang di Taiwan mengkonsumsi rata-rata dibawah 50 kilogram beras setiap tahun. Secara umum pasokan dan permintaan beras terlihat stabil, tetapi sebetulnya ini mengundang kekhawatiran banyak pihak di Taiwan akan adanya krisis pangan yang diakibatkan berubahnya gaya hidup. Karena orang telah mengubah kebiasaan diet mereka, Taiwan harus mengimpor sejumlah besar makanan yang dulunya masih sangat asing sebagai pengganti nasi misal kedelai, gandum dan jagung, atau bahkan sorghum.

Selain itu juga dengan adanya diversifikasi beras di Taiwan diharapkan bisa menyumbang terhadap konsensus global konservasi lingkungan, dengan mengkonsumsi makanan lokal juga akan membuatnya ramah lingkungan dengan memutus rantai pasokan dan permintaan, menghemat energi yang digunakan untuk transportasi serta mencapai tujuan perlindungan lingkungan dengan mengurangi polusi karbon.
Dalam rangka merevitalisasi penggunaan beras, banyak kalangan mengupayakan dengan banyak berinvestasi dalam penelitian pemasaran bidang pertanian dengan menentukan segmentasi yang terukur, sehingga setiap petani sudah bisa menyesuaikan kemampuannya dengan kebutuhan pasar. Peranan asosiasi petani dalam memberikan penanganan terhadap pemasaran dengan membuat merk sendiri dan standard kualitas terukur cukup signifikan.Beras produksi khusus dan zona pemasaran, untuk mengatasi dampak dari beras impor pada industri beras dalam negeri, kementerian pertanian Taiwan menentukan segmentasi pasar untuk menonjolkan karakteristik dan kualitas merek lokal. Beras produksi khusus dan zona pemasaran juga diluncurkan dengan menggabungkan petani, pemasok bibit, dan pabrik bersama-sama untuk memperbesar skala manajemen dan sekaligus menurunkan biaya produksi.

Produksi beras pada tahun 2010 adalah 1.016.000 metrik ton dari 244.000 hektar. Produksi padi untuk 2012 adalah 1.096.000 metrik ton dari 268.000 hektar berdasarkan hasil normal. Taiwan memiliki 302 asosiasi petani, dan 17 asosiasi irigasi yang menyediakan 2.3 juta petani dan pelayanan yang luas seperti suplai produk material, transportasi produk, asuransi kesehatan petani, 
penyediaan kredit dan lain lain yang diupayakan untuk memaksimalkan produksi beras.Telah terjadi penurunan bertahap dalam konsumsi beras dan produksi. Selain itu, produsen beras yang terkena persaingan dari impor, beras masih masuk dalam peringkat sebagai tanaman Taiwan yang paling berharga, dengan hasil total lebih dari 1,67 juta ton dari 254.225 hektar lahan untuk nilai produksi NT \$ 38,1 milyar (US \$ 1,29 miliar) pada tahun 2011.

Untuk memastikan kelangsungan hidup masa depan dan meningkatkan harga, pertanian di Taiwan menyempurnakan teknik budidaya padi dan mengembangkan varietas berkualitas tinggi, banyak yang sudah tersedia secara umum. Kualitas juga telah ditingkatkan dengan promosi akreditasi produk pertanian dan sistem traceability makanan serta sistem penilaian yang bertujuan mengeluarkan produksi beras rendah.

Diversifikasi yang paling menarik dalam pemasarannya tentu saja beras organik, yang kembali menduduki popularitas tertinggi dan menjadi bahan unggulan ekspor ke jepang meski dalam jumlah terbatas, beras organik hampir dua kali lipat harganya dalam pemasaran pertanian daerah, dan sekarang berkembang menjadi seluas 1.653 hektar pada Desember 2011. Sektor pertanian padi telah direvitalisasi dengan kompetisi beras premium yang disponsori setiap tahun oleh pemerintah dan pemasaran baik yang meliputi lomba mengemas produk dan menyediakan hadiah sebagai penghargaanterhadap petani. Hal ini juga diuntungkan dari program pertanian kontrak yang dilakukan oleh perusahaan Taiwan untuk membeli semua beras hasil panen dari ladang yang dipilih sebelum menanam.

. Taiwan dalam ketersediaan beras di pasar menggunakan strategi pasar yang berbeda untuk merespon pasar pasca masuk menjadi anggota WTO. Pabrik pabrik besar memegang peranan cukup besar yang mengkordinir petani di seluruh negeri. Pengusaha padi diawasi oleh pemerintah Taiwan baik yang melakukan impor dan investasi di penggilingan baru, maupun kemasan, fasilitas peningkatan kemampuan beras lokal ini ditujukan untuk meningkatkan kualitas beras agar dapat bersaing dengan beras impor.

Kementerian Pertanian Taiwan, telah merevisi kebijakan produksi pertanian untuk meningkatkan swasembada pangan secara bertahap menyesuaikan ke atas produksi berasnya dengan menyimpan cadangan beras sebesar 400 TMT (thousand metric ton) (352 TMT atau setara dengan beras putih). Tujuan Taiwan adalah untuk mencapai 40 persen makanan tingkat 
swasembada keseluruhan pada tahun 2020 dari tingkat saat ini sekitar 32 persen seperti yang dilaporkan oleh COA. (3\% per bulan dari total peredaran beras yang ada di pasar Taiwan)

Untuk meningkatkan stok beras, beras target produksi Taiwan diperkirakan akan tumbuh sebesar delapan persen menjadi280.000 hektar pada tahun 2013, memproduksi 1.175 MMT(million metrics ton) . Pada tahun 2011, Taiwan produksi beras terutama disebabkanuntuk surplus dengan hasil normal dari $5.873 \mathrm{~kg} / \mathrm{ha}$ (gabah) untuk panen pertama dan $4.431 \mathrm{~kg} \mathrm{/} \mathrm{ha}$ untukpanen kedua. Hal ini naik apabila dibandingkan dengan lima tahun yang lalu berkisar di $5.343 \mathrm{~kg} /$ ha untuk panen pertamadan $3.774 \mathrm{~kg} /$ ha untuk tanaman kedua.Pembelian beras dalam negeri merupakan program pemerintah, Taiwan mendirikan program untuk pembelian beras dalam negeri sejak tahun 1974 . Pada tanggal 29 April 2011,COA mengumumkan kenaikan harga pembelian dasar NT\$ 3/kg harga untuk pembelian padi domestik. SebagaiAkibatnya, program penjualan padi kepada pemerintah di bawah program pembelian beras meningkat dua kali lipat dari 191 TMTpada tahun 2010 menjadi 384 TMT (thousand metric ton) tahun 2011.

Mengingat tingkat stok beras yang tinggi, target produksi perkiraan untuk
2013 akan tergantung pada apakah konsumsi beras meningkat di kalangan masyarakat Taiwan. AFA mengacu pada harga grosir domestik sebagai indikator ketika mereka melakukan perbandingan harga antara domestik dan beras AS harga. Semua data beras dalam negeri yang bersumber dari AFA dan tersedia secara online dari website COA di http:// www.coa.gov.tw. Program pembelian beras diatur dalam kebijakan operasional lapangan di pasar dengan COA mengumumkan harga pokok penjualan yang berlaku, pemerintah telah melakukan pembelian terhadap petani, meskipun dengan harga tinggi tapi demi melindungi petani pemerintah Taiwan menetapkan harga cukup tinggi dan melakukan subsidi silang dengan sector lain yang sudah maju, misal industri

Harga beras dalam negeri juga menanggapi pengumuman ini denganharga grosir rata-rata harian beras Japonica giling selama periode Mei 2011 April 2012meningkat menjadi NT \$ 34,23 dibandingkan dengan selama periode Mei 2010 - April 2011 rata-rata NT \$30,44 / kg. Taiwan memproduksi tanaman padi dua kali per tahun. Dalam setiap tahun, hanya ada variasi kecil di daerah produksi dan hasil. Variabel utama adalah cuaca, karena topan cenderung merusak panen kedua setiap tahun. Produksi beras pada tahun 2010 adalah 1.016 .000 metrik ton 
dari 244.000 hektar. Produksi padi Target untuk 2011 adalah 1.096.000 metrik ton dari 268.000 hektar berdasarkan hasil normal.

Untuk menambah ketertarikan pembeli. Setelah dilakukan klasifikasi mutu beras, kemudian dikeluarkan peraturan tentang membedakan tingkat kualitas. Misalnya dengan melihat tampak luar beras dan penilaian rasa maka kualitas beras dapat dibedakan menjadi: (i) Beras berkualitas, (ii) Beras biasa, dan (iii) Beras jelek. Tiga tingkatan kualitas yang berbeda kemudian digunakan sebagai standar untuk menguji kualitas beras di tiap daerah. Kualitas beras selain dipengaruhi oleh jenis padi sendiri juga dari faktor lokasi penanaman, cuaca waktu penanaman, teknik penanaman, proses panen, pengelolahan dan penyimpanan serta faktor lainnya. Pengaruh jenis padi dan lokasi terhadap kualitas beras tidaklah sama untuk tiap daerah. Dengan rnemahami kondisinya, maka perlu dilakukan penyesuaian jenis padi berkualitas pada tiap daerah. Perubahan pada kualitas beras dan masalah kualitas beras pecah kulit dan lainnya dapat diberikan pilihan lokasi pengernbangan di masa depan dan peraturan pembedaan tingkat kualitas sebagai pedoman.

\section{KESIMPULAN}

Beras merupakan makanan pokok paling penting di Taiwan. Badan Pertanian dan Pangan (AFA) dibawah kordinasi kementerian pertanian (COA) telah melaksanakan berbagai langkah untuk mendukung pembangunan berkelanjutan dari industri beras, yang meliputi produksi yang direncanakan, pemuliaan varietas baru, memperbaiki teknik budidaya, menganjurkan penggunaan bahan kimia yang tepat untuk kontrol hama, membangun produksi beras khusus dan zona pemasaran, mendorong diberlakukannya sistem pengendalian mutu, dan mempromosikan sistem sertifikasi CAS untuk komoditas padi.

Tujuan lain selain memberikan kemudahan produksi beras dalam sebuah sistem manajemen, juga secara signifikan meningkatkan kualitas dan daya saing beras di pasar lokal dan internasional. Untuk memperkuat pemasaran beras dalam negeri, Pihak terkait di Taiwan membantu asosiasi petani lokal 'untuk membangun merek mereka sendiri dan mengadopsi strategi pemasaran dengan diversifikasi. Badan ini juga menjalankan program pendidikan memperkenalkan budaya tradisional dan sejarah terkait dengan industri beras kepada masyarakat dalam rangka untuk mempromosikan konsumsi beras lokal. 
Strategi mengamankan informasi mengenai produksi dan pemasaran beras, mempromosikan sistem penilaian padi, dan memeriksa kualitas dan status higienis di pasar ritel, tujuan penyimpanan keamanan pangan dan perlindungan konsumen yang tepat telah tercapai dengan baik.Menurut kementerian Pertanian (COA) "Neraca makanan", konsumsi per kapita beras adalah $48 \mathrm{~kg}$ pada tahun 2009. Otoritas Taiwan mempromosikan konsumsi beras dan harapan bahwa konsumsi per kapita akan meningkat menjadi $51 \mathrm{~kg}$ pada akhir tahun 2014, sehingga meningkatkan energi tertimbang swasembada pangan tingkat ke $32.72 \%$ dari $32 \%$ pada tahun 2009. Otoritas Taiwan ingin membalikkan penurunan per kapita konsumsi beras sebagai cara untuk mengurangi impor gandum.

Saran untuk Indonesia. Taiwan dengan Negara lebih dari 90\% swasembada produksi beras, dengan pasar beras stabil dalam negeri. Sebagaimana dicatat, Taiwan telah melakukan upaya untuk mempromosikan konsumsi beras meningkat sebagai pengganti impor gandum. Dalam pemasaran (pembelian dan penjualan), apabila tidak memperhatikan perbedaan tingkat kualitas maka harga beras berkualitas dan harga beras biasa tidak akan ada perbedaan harga.
Hal ini akan membuat para petani tidak memiliki semangat untuk menanam padi. Memahami perubahan kualiias pada jenis padi berkualitas yang disarankan untuk ditanam di lokasi yang berbeda melalui peraturan pemisahan jenis dan tingkat kuallitas dapat digunakan sebagai pedoman lokasi penanaman padi berkualitas dan menerapkan penjualan padi dengan tingkatan harga yang berbeda.Untuk prospek masa depan Indonesia , Sebagai langkah aplikatif dan prospek masa depan, yang harus diaplikasikan dalam sistem produksi beras di Indonesia adalah :

1. Memaksimalkan produksi beras, dengan maksimal setidaknya, untuk swasembada karena beras merupakan makanan pokok makanan untuk Indonesia, dengan menambah perluasan lahan sawah di beberapa daerah yang potensial dan didukung oleh asas-asas konservasi.

2. Indonesia harus bisa mencontoh konsistensi dan pemerataan pembangunan misal harus mempertahankan/menambah sistem irigasi dan drainase, dalam hal kebutuhan, pertumbuhan padi masa tanam bisa berlanjut dengan normal.

3. Berbeda dengan Taiwan, Indonesia lebih harus menitikberatkan ke kuantitas, sambil diiringi kualitas secara bertahap. Taiwan masih lebih 
baik hanya menekankan pada produksi beras berkualitas baik untuk memenuhi kebutuhan konsumen lokal, meskipun konsumsi terhadap beras semakin turun.

4. Beras harus dapat di rotasi ke daerah daerah yang potensial untuk lahan persawahan, dengan diimbangi diversifikasi berdasarkan kearifan lokal untuk menurunkan ketergantungan Indonesia terhadap beras.

5. Meningkatkan daya saing pemasaran untuk industri beras dengan memilih benih, penyediaan pupuk, subsidi dan peningkatan diversifikasi fungsi lahan dengan tidak mengurangi produksi yang ada.

6. Impor sebagai salah satu indikator kuat penentuan harga di Indonesia, dikurangi dengan memperbanyak pembelian beras ke petani, dan melakukan pembangunan gudang penyimpanan yang tersebar merata di seluruh Indonesia.

7. Semakin diperbanyaknya penelitian dan kerjasama lintas riset untuk membuat benih yang berkualitas berdasarkan karakteristik wilayah yang ada di Indonesia

8. Dibukanya akses-akses perlindungan terhadap petani dalam aspek aspek manajemen, ketersediaan alat, dan subsidi yang berimbang sesuai dengan peraturan yang berlaku.

9. Penerapan Kebijakan dari atas sampai ke bawah harus konsisten, dengan adanya UU yang berlaku dan rencana strategis pengembangan pertanian Indonesia bersinergi dengan semua stakeholder.

\section{DAFTAR PUSTAKA}

Amin, M., Djankov, S., 2009. Determinants of Doing Business Reforms Enterprise Note No. 7. The World Bank, Washington, DC.

Kementerian perdagangan Republik Indonesia.2010. Rencana Strategis Kementerian Perdagangan periode 2010-2014.

Kementerian Pertanian Republik Indonesia.2011. Rencana Strategis Kementerian Pertanian 2010-2014.

CEPD, 2011.Taiwan Statistical Data Book, Council for Economic Planning and Development, Executive Yuan, R.O.C. (Taiwan) Edition: First edition ISSN: 1016-2224 July 2011.

Chang, T.-T. 1985. Crop history and genetic conservation: rice - a case study. Iowa State J. Res. 59:425-455. 
Everage, Laura (October 1, 2002). "Understanding the LOHAS Lifestyle".Gourmet Retailer Magazine (Nielsen Business Media).

Grist D.H., 1960. Rice. Formerly Agricultural Economist, Colonial Agricultural Service, Malaya. Longmans, Green and Co Ltd. London.

Hanks, L.M. 1972. Rice and Man. Aldine-Atherton, Inc. 16-22.

Hartwell, J.L. 1967-1971. Plants used against cancer. A survey. Lloydia 30-34.

KDARES, 2011. Profile organization. Kaohsiung district agriculture research and extension. Taiwan

Khush, G.S. 1997. Origin, dispersal, cultivation and variation of rice. Plant Molecular Biology 35: 25-34.

Londono-Kent, ,Maria del Pilar, and Paul E. Kent. 2003 "A Tale of Two Ports: The Cost of Inefficiency." Report for the World Bank,.

Luh, B.S., 1991. Rice Production, Volume I.Published by Van Nostrand Reinhold, New York

Oka, H. 1974. Experimental studies on the origin of cultivated rice. Genetics 78:475-486

Rodrik, D., 2004. Industrial policy for the twenty-first century. Harvard University Kennedy School of Government Faculty Research Working Paper Series RWP04-047, Cambridge, MA.

Wooldridge, M Jeffrey, 2002. Econometric analysis of cross section and panel data. Massachusetts Institute of Technology

\section{Website:}

Kementerian pertanian Taiwan: www.coa.gov.tw

Biro pusat statistik: Taiwan www.cepd.gov.tw

Perwakilan Indonesia di Jakarta: www.kdei-taipei.org

Kementrian Perdagangan RI: www.kemendag.go.id

Global Agricultural Information Network Online: http://gain.fas.usda.gov

Easy Agritourism: http://ezgo.coa.gov.tw

Pingtung Agricultural Biotechnology Park: http://www.pabp.gov.tw

Safe Agricultural Industry Web Portal (Chinese only): http://agsafe.coa.gov.tw

Taiwan Agriculture and Food Traceability System (Chinese only): http://taft.coa.gov.tw

Taiwan Agriculture Land Information Service (Chinese only): https://talis.coa.gov.tw/asso

The Farmers' Academy (Chinese only): http://academy.coa.gov.tw 